\title{
Assessment of Left Atrial Volume Index in the Patients with ACS in Adults
}

\author{
Niranjan Reddy R ${ }^{\odot}$, Shashanka Chunduri ${ }^{\circledR}$ \\ Assistant Professor, Department of Cardiology, Sapthagiri Institute of Medical Sciences and Research Centre, Bangalore, Karnataka, India.
}

\section{Abstract}

Background: Atherosclerotic cardiovascular disease (ASCVD) is the leading cause of death universally. The present study was conducted to assess LA volume index (LAVI) in the patients with ACS in adults. Subjects and Methods: The present study was conducted on 120 adult patients diagnosed with ACS of both genders in narayana medical college hospital from May 2016 toOctober 2016. Patients were divided into 2 groups of 60 each. Group I patients had LAVI $>34 \mathrm{ml} / \mathrm{m}^{2}$ and group II patients had LAVI $\leq 34 \mathrm{ml} / \mathrm{m}^{2}$. The LV systolic function was analyzed by Simpson's disc volumetric method. The LAV was assessed by the biplane area-length method from apical 4-chamber and 2-chamber views. Results: The mean BMI in group I patients was $26.7 \mathrm{~kg} / \mathrm{m}^{2}$ and in group II was $26.1 \mathrm{~kg} / \mathrm{m}^{2}$, AW STEMI in group I was seen in 30 patients and in group II in 32, IW + PW STEMI in 6 and 4 patients in both groups respectively, IW STEMI in 5 and 4 patients respectively, NSTEMI in 4 and 3 patients respectively and UA in 15 and 17 patients respectively. Risk factors were diabetes mellitus in 32 and 27 patients respectively, hypertension in 41 and 40 patients respectively, smoking in 43 and 38 patients respectively, alcohol in 30 and 35 patients respectively and positive family history in 12 and 16 patients respectively. The difference was non- significant ( $\mathrm{P}>0.05)$. The mean LAVI at admission in group I was 38.1 and in group II was 27.2, after 1 month was 40.2 and 28.1 in both groups, after 6 months was 39.1 and 27.9 in both groups and after 12 months was 42.7 and 25.3 in both groups respectively. The difference was significant $(\mathrm{P}<0.05)$. Conclusion: Authors conclude that LAVI was found to be the independent predictor of mortality than left ventricular ejection fraction on multivariate regression analysis. Common risk factors in patients with ACS were diabetes mellitus, hypertension, smoking, alcoholism and positive family history. Patients with LAVI of value $>34 \mathrm{ml} / \mathrm{m}^{2}$ were associated with increased comorbidities.

Keywords: Acute Coronary Syndrome, Diabetes Mellitus, Left Atrial Volume Index

Corresponding Author: Shashanka Chunduri, Assistant Professor, Department of Cardiology, Sapthagiri Institute of Medical Sciences and Research Centre, Bangalore, Karnataka, India.

E-mail: shashankadr@gmail.com

Received: 13 February 2020

\section{Introduction}

Atherosclerotic cardiovascular disease (ASCVD) is the leading cause of death universally. It has been reported that in year $2015,31 \%$ of global deaths were due to ASCVD. ${ }^{[1]}$ It considered to be inflammatory disorder. It has slow progression. It can manifest as stroke, coronary heart disease (CHD), peripheral artery disease and aortic aneurysm. It is one of the major causes of mortality in the world both in developing and developed countries. ${ }^{[2]}$

Among all, CHD is one of the major disorders encountered over $50 \%$ of adults. ${ }^{[3]}$ Clinical assessment should be conducted to search for all cardiovascular risk factors and clinical conditions that may manipulate prognosis and treatment, to evaluate the presence of target organ damage, to assess those at high risk and in need of urgent intervention ant to assess those who need special investigations or referral. ${ }^{[4]}$

Acute coronary syndrome (ACS) refers to a spectrum of clinical presentations ranging from those of ST segment elevation myocardial infarction (STEMI) to presentation in non STEMI (NSTEMI) or unstable angina (UA). ${ }^{[5]}$ The left ventricular (LV) function is an important prognostic marker for patients with ACS. The left atrial volume (LAV) is considered to be the predictor of the CV outcomes. ${ }^{[6]}$ The present study was conducted to assess LA volume index (LAVI) in the patients with ACS in adults.

\section{Subjects and Methods}

The present study was conducted in the department of Cardiology in narayana medical college hospital from May 2016 to October 2016. Patients were divided into 2 groups of 
comprised of 120 adult patients diagnosed with ACS of both genders. The study protocol was approved from institutional ethical committee. All patients were informed and written consent was obtained.

Patient particular such as name, age, gender etc. was recorded. A cutoff of LAVI $\leq 34 \mathrm{ml} / \mathrm{m}^{2}$ was considered as normal as per the 2015 American Society of Echocardiography Chamber Quantification guidelines. All patients were subjected to electrocardiogram (ECG). Other parameters such as height, weight, body mass index (BMI) and routine blood investigation such as hemoglobin, TLC, DLC, blood urea, serum creatinine, RBS, serum electrolytes, lipid profile, blood grouping and viral markers were assessed. Based on ECG findings, patients were divided into 2 groups of 60 each. Group I patients had LAVI $>34 \mathrm{ml} / \mathrm{m}^{2}$ and group II patients had LAVI $\leq 34 \mathrm{ml} / \mathrm{m}^{2}$. The LV systolic function was analyzed by Simpson's disc volumetric method. The LAV was assessed by the biplane area-length method from apical 4-chamber and 2 -chamber views. Each patient was assessed clinically and echocardiographically at 1,6 , and 12 months. Results thus obtained were subjected to statistical analysis. P value less than 0.05 was considered significant.

\section{Results}

\begin{tabular}{|c|c|c|c|}
\hline Parameters & Group I & Group II & P value \\
\hline $\begin{array}{l}\text { BMI } \\
\left(\mathrm{kg} / \mathrm{m}^{2}\right)\end{array}$ & 26.7 & 26.1 & 0.92 \\
\hline AW STEMI & 30 & 32 & 0.88 \\
\hline $\begin{array}{l}\text { IW + PW } \\
\text { STEMI }\end{array}$ & 6 & 4 & 0.91 \\
\hline IW STEMI & 5 & 4 & \\
\hline NSTEMI & 4 & 3 & \\
\hline UA & 15 & 17 & \\
\hline \multicolumn{4}{|l|}{ Risk factors } \\
\hline $\begin{array}{l}\text { Diabetes } \\
\text { mellitus }\end{array}$ & 32 & 27 & 0.12 \\
\hline Hypertension & 41 & 40 & 0.91 \\
\hline Smoking & 43 & 38 & 0.15 \\
\hline Alcohol & 30 & 35 & 0.21 \\
\hline $\begin{array}{l}\text { Family his- } \\
\text { tory }\end{array}$ & 12 & 16 & 0.32 \\
\hline
\end{tabular}

Table 1 shows that mean BMI in group I patients was 26.7 $\mathrm{kg} / \mathrm{m}^{2}$ and in group II was $26.1 \mathrm{~kg} / \mathrm{m}^{2}$, AW STEMI in group I was seen in 30 patients and in group II in 32, IW + PW STEMI in 6 and 4 patients in both groups respectively, IW STEMI in 5 and 4 patients respectively, NSTEMI in 4 and 3 patients respectively and UA in 15 and 17 patients respectively. Risk factors were diabetes mellitus in 32 and 27 patients respectively, hypertension in 41 and 40 patients respectively, smoking in 43 and 38 patients respectively, alcohol in 30 and 35 patients respectively and positive family history in 12 and 16 patients respectively. The difference was non- significant $(\mathrm{P}>0.05)$.

\begin{tabular}{|c|c|c|c|}
\hline Parameters & Group I & Group II & $P$ value \\
\hline $\begin{array}{l}\text { LAVI AL } \\
\text { method } \\
\left(\mathrm{ml} / \mathrm{m}^{2}\right)\end{array}$ & 38.1 & 27.2 & 0.001 \\
\hline $\mathrm{E} / \mathrm{e}^{\prime}$ & 14.8 & 13.1 & 0.05 \\
\hline $\mathrm{PV}(\mathrm{cm} / \mathrm{s})$ & 32.4 & 46.2 & 0.01 \\
\hline E/PV & 2.8 & 2.3 & 0.02 \\
\hline $\begin{array}{l}\text { LVEF } \\
\text { Simpson's } \\
\text { method }\end{array}$ & 38.7 & 45.1 & 0.001 \\
\hline $\begin{array}{ll}\text { LA } & \text { ESV } \\
(\mathrm{ml}) & \end{array}$ & 55.4 & 40.3 & 0.01 \\
\hline
\end{tabular}

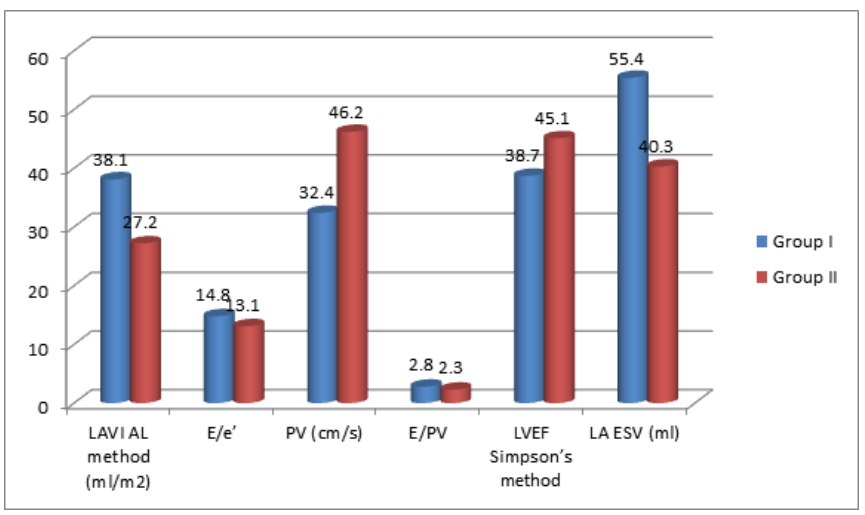

\section{Figure 1: Echocardiographic parameters in both groups}

Table 2, Figure 1 shows that mean value for LAVI with AL method was $38.1 \mathrm{ml} / \mathrm{m}^{2}$ in group I and $27.2 \mathrm{ml} / \mathrm{m}^{2}$ in group II, E/e' was 14.8 in group I and 13.1 in group II, $\mathrm{PV}(\mathrm{cm} / \mathrm{s})$ was 32.4 in group I and 46.2 in group II, E/PV was 2.8 in group I and 2.3 in group II, Left ventricular ejection fraction (LVEF) by Simpson's method was 38.7 in group I and 45.1 in group II and LA ESV (ml) was 55.4 in group I and 40.3 in group II. The difference was significant $(\mathrm{P}<0.05)$.

Table 3, Figure 2 shows that mean LAVI at admission in group I was 38.1 and in group II was 27.2, after 1 month was 40.2 and 28.1 in both groups, after 6 months was 39.1 and 27.9 in both groups and after 12 months was 42.7 and 25.3 in both groups respectively. The difference was significant $(\mathrm{P}<0.05)$. 
Table 3: Comparison of left atrial volume index (LAVI) in both groups

\begin{tabular}{llll}
\hline Parameters & Group I & Group II & P value \\
$\begin{array}{l}\text { At admis- } \\
\text { sion }\end{array}$ & 38.1 & 27.2 & 0.001 \\
1 month & 40.2 & 28.1 & 0.01 \\
6 months & 39.1 & 27.9 & 0.01 \\
12 months & 42.7 & 25.3 & 0.001 \\
\hline
\end{tabular}

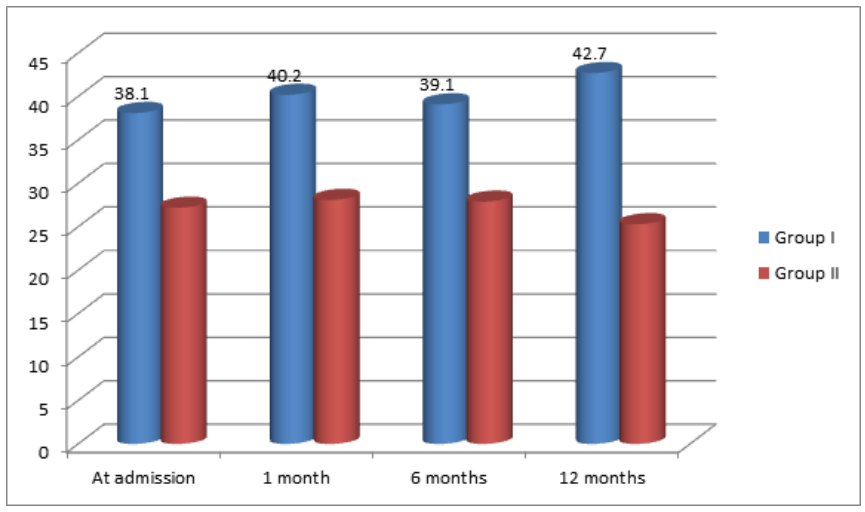

Figure 2: Comparison of left atrial volume index (LAVI) in both groups

\section{Discussion}

Acute coronary syndrome (ACS) is among the main causes of hospital morbidity and mortality nowadays. Cardiovascular risk factors for acute coronary syndrome (ACS) are on the rise in people of Indian origin. ${ }^{[7]}$ Acute coronary syndrome refers to any group of clinical symptoms compatible with acute myocardial ischemia and covers the spectrum of clinical conditions ranging from unstable angina (UA) to non- STsegment elevation myocardial infarction (NSTEMI) to STsegment elevation myocardial infarction (STEMI). A LAVI of value $32 \mathrm{ml} / \mathrm{m}^{2}$ was found to be the independent predictor of all-cause mortality. ${ }^{[8]}$ The present study was conducted to assess the relationship of the LA volume index (LAVI) with the clinical presentation in the patients with ACS in adults.

In present study, patients were divided into 2 groups based on LAVI. Group I patients had LAVI $>34 \mathrm{ml} / \mathrm{m}^{2}$ and group II patients had LAVI $\leq 34 \mathrm{ml} / \mathrm{m} 2$. We found that mean BMI in group I patients was $26.7 \mathrm{~kg} / \mathrm{m}^{2}$ and in group II was 26.1 $\mathrm{kg} / \mathrm{m}^{2}$, AW STEMI in group I was seen in 30 patients and in group II in 32, IW + PW STEMI in 6 and 4 patients in both groups respectively, IW STEMI in 5 and 4 patients respectively, NSTEMI in 4 and 3 patients respectively and UA in 15 and 17 patients respectively. Nagula et al, ${ }^{[9]}$ conducted a study on 160 ACS patients which were divided into Group A $\left(\right.$ LAVI $\left.>34 \mathrm{ml} / \mathrm{m}^{2}\right)$ and Group B (LAVI $\left.\leq 34 \mathrm{ml} / \mathrm{m}^{2}\right)$. The echocardiographic $\mathrm{E}$ wave velocity divided by propagation velocity had a positive correlation with the LAVI. The relative risk of morbidity with an increased LAVI was 2.74. The hazard ratio for adverse events in patients with increased LAVI was 2.81. The total number of deaths was 21 (16 and 5 in Group A and B). The LAVI was found to be the independent predictor of mortality than left ventricular ejection fraction on multivariate regression analysis. The receiver operating characteristic curve analysis had an area under the curve of 0.801 for increased LAVI.

Atherosclerosis is the ongoing process of plaque formation that involves primarily the intima of large- and medium-sized arteries; the condition progresses relentlessly throughout a person's lifetime, before finally manifesting itself as an acute ischemic event. Various risk factors are hypercholesterolemia, hypertension, diabetes, and smoking, alcoholism and positive family history. ${ }^{[10]}$ In present study risk factors were diabetes mellitus in 32 and 27 patients respectively, hypertension in 41 and 40 patients respectively, smoking in 43 and 38 patients respectively, alcohol in 30 and 35 patients respectively and positive family history in 12 and 16 patients respectively.

We observed that mean value for LAVI with AL method was $38.1 \mathrm{ml} / \mathrm{m}^{2}$ in group I and $27.2 \mathrm{ml} / \mathrm{m}^{2}$ in group II, E/e' was 14.8 in group I and 13.1 in group II, PV $(\mathrm{cm} / \mathrm{s})$ was 32.4 in group I and 46.2 in group II, E/PV was 2.8 in group I and 2.3 in group II, Left ventricular ejection fraction (LVEF) by Simpson's method was 38.7 in group I and 45.1 in group II and LA ESV $(\mathrm{ml})$ was 55.4 in group I and 40.3 in group II.

Gunasekaran et al, ${ }^{[1]}$ in their study conducted on 75 patients, 32 had increased LAVI and 43 had normal LAVI. 55\% of the patients were diagnosed with unstable angina. During the follow-up period of 6 months, 30 patients (93.8\%) in the increased-LAVI arm and 23 patients $(53.5 \%)$ in the normal-LAVI arm developed at least a single MACE. Authors suggested that an increased LAVI $\left(>28 \mathrm{ml} / \mathrm{m}^{2}\right)$ is an independent predictor for MACES 6 months after ACS. LAVI $>50 \mathrm{ml} / \mathrm{m}^{2}$ predicts HF hospitalization and mortality with similar statistical power as LVEF.

We found that mean LAVI at admission in group I was 38.1 and in group II was 27.2, after 1 month was 40.2 and 28.1 in both groups, after 6 months was 39.1 and 27.9 in both groups and after 12 months was 42.7 and 25.3 in both groups respectively.

Poulsen et al, ${ }^{[12]}$ conducted a study on 305 T2DM patients without known CVD. LAVI $\geq 32 \mathrm{ml} / \mathrm{m}^{2}$ was found in 105 patients (34\%). During follow-up, 60 patients $(20 \%)$ experienced the composite endpoint, of whom $28(9 \%)$ died. Patients with LAVI $\geq 32 \mathrm{ml} / \mathrm{m}^{2}$ had a significantly higher cardiac event rate and death rate. Authors found that there is an independent association of increased LAVI with the duration 
of diabetes and the presence of comorbidities in the diabetic population.

\section{Conclusion}

Authors conclude that LAVI was found to be the independent predictor of mortality than left ventricular ejection fraction on multivariate regression analysis. Common risk factors in patients with ACS were diabetes mellitus, hypertension, smoking, alcoholism and positive family history. Patients with LAVI of value $>34 \mathrm{ml} / \mathrm{m}^{2}$ were associated with increased comorbidities.

\section{References}

1. O'gara PT, Kushner FG, Ascheim DD, Casey DE, Chung $\mathrm{MK}$, Lemos JAD. ACCF/AHA guideline for the management of ST elevation myocardial infarction: A report of the American College of Cardiology Foundation/American Heart Association Task Force on practice guidelines. Circulation. 2013;127:362-425. Available from: https://dx.doi.org/10. 1161/cir.0b013e3182742cf6.

2. Thygesen K, Alpert JS, Jaffe AS, Simoons ML, Chaitman BR, White HD. Third universal definition of myocardial infarction. J Am Coll Cardiol. 2012;60:1581-98.

3. Nagueh SF, Appleton CP, Gillebert TC, Marino PN, Oh JK, Smiseth OA, et al. Recommendations for the Evaluation of Left Ventricular Diastolic Function by Echocardiography. J Am Soc Echocardiogr. 2009;22(2):107-133. Available from: https://dx.doi.org/10.1016/j.echo.2008.11.023.

4. Lang RM, Badano LP, Moravi V, Afilalo J, Armstrong A, Ernande L. Recommendations for cardiac chamber quantification by echocardiography in adults: An update from the American Society of Echocardiography and the European Association of Cardiovascular Imaging. J Am Soc Echocardiogr. 2015;28:1-39. Available from: https://dx.doi. org/10.1016/j.echo.2014.10.003.

5. Ristow B, Ali S, Whooley MA, Schiller NB. Usefulness of Left Atrial Volume Index to Predict Heart Failure Hospitalization and Mortality in Ambulatory Patients With Coronary Heart Disease and Comparison to Left Ventricular Ejection Fraction (from the Heart and Soul Study). Am J Cardiol. 2008;102(1):70-76. Available from: https://dx.doi.org/10. 1016/j.amjcard.2008.02.099.

6. Simek CL, Feldman MD, Haber HL, Wu CC, Jayaweera AR, Kaul S. Relationship between left ventricular wall thickness and left atrial size: Comparison with other measures of diastolic function. J Am Soc Echocardiogr. 1995;8(1):37-47. Available from: https://dx.doi.org/10.1016/s0894-7317(05)80356-6.

7. Møller JE, Søndergaard E, Poulsen SH, Egstrup K. Pseudonormal and restrictive filling patterns predict left ventricular dilation and cardiac death after a first myocardial infarction: a serial color M-mode doppler echocardiographic study. J Am Coll Cardiol. 2000;36(6):1841-1846. Available from: https: //dx.doi.org/10.1016/s0735-1097(00)00965-7.

8. Kou S, Caballero L, Dulgheru R, Voilliot D, Sousa CD, Kacharava G, et al. Echocardiographic reference ranges for normal cardiac chamber size: results from the NORRE study. Eur Heart J Cardiovasc Imaging. 2014;15(6):680-690. Available from: https://dx.doi.org/10.1093/ehjci/jet284.

9. Nagula P, Yerrabandi SRV, Otikunta AN, Karumuri S. A clinical study of prognostic significance of left atrial volume index in patients with acute coronary syndrome. J Ind Coll Cardiol. 2019;9(4):186-186. Available from: https://dx.doi. org/10.4103/jicc.jicc_39_19.

10. Thygesen K, Alpert JS, Jaffe AS, Simoons ML, Chaitman BR, White HD. Third universal definition of myocardial infarction. J Am Coll Cardiol. 2012;60:1581-98.

11. Gunasekaran R, Maskon O, Hassan HHC, Safian N, Sakthiswary R. Left Atrial Volume Index Is an Independent Predictor of Major Adverse Cardiovascular Events in Acute Coronary Syndrome. Can J Cardiol. 2012;28(5):561-566. Available from: https://dx.doi.org/10.1016/j.cjca.2012.02.015.

12. Poulsen MK, Dahl JS, Henriksen JE, Hey TM, Høilundcarlsen $\mathrm{PF}$, Nielsen B, et al. Left atrial volume index: Relation to long term clinical outcome in type 2 diabetes. J Am Coll Cardiol. 2013;62:2416-2437.

Copyright: (C) the author(s), 2020. It is an open-access article distributed under the terms of the Creative Commons Attribution License (CC BY 4.0), which permits authors to retain ownership of the copyright for their content, and allow anyone to download, reuse, reprint, modify, distribute and/or copy the content as long as the original authors and source are cited.

How to cite this article: Reddy R N, Chunduri S. Assessment of Left Atrial Volume Index in the Patients with ACS in Adults. Acad. J Med. 2020;3(1):23-26.

DOI: dx.doi.org/10.47008/ajm.2020.3.1.6

Source of Support: Nil, Conflict of Interest: None declared. 